\title{
Hygienic sanitary conditions of vacuum packed beef produced by slaughterhouses qualified for export in the Mato Grosso state, Brazil
}

\author{
Maxsueli Aparecida Moura Machado ${ }^{1}$ Barbara Müller $^{2}$ \\ Ricardo César Tavares Carvalho ${ }^{2}$ Eduardo Eustáquio de Souza Figueiredo ${ }^{2,3^{*}}$
}

${ }^{1}$ Graduação em Ciência e Tecnologia de Alimentos, Faculdade de Nutrição, Universidade Federal de Mato Grosso (UFMT), Cuiabá, MT, Brasil. ${ }^{2}$ Programa de Pós-graduação em Nutrição Alimentos e Metabolismo, Universidade Federal de Mato Grosso (UFMT), Cuiabá, MT, Brasil. ${ }^{3}$ Programa de Pós-graduação em Ciência Animal, Universidade Federal de Mato Grosso (UFMT), Av. Fernando Correa da Costa, 2367, 78060-900,Cuiabá, MT, Brasil. E-mail: figueiredoeduardo@ufmt. *Corresponding author.

\begin{abstract}
Brazil is the largest exporter of beef of the world and Mato Grosso State is the highest beef producer in this country. To maintain product competitiveness and market expansion, sanitary hygienic control of the entire process is indispensable to ensure the attainment of harmless beef and quality. The objective of this study was to evaluate the hygienic sanitary conditions of vacuum-packed beef produced by establishments qualified for export in the state of Mato Grosso, Brazil. A total of 60 samples were submitted to coliforms counts at $35^{\circ} \mathrm{C}$ and at $45^{\circ} \mathrm{C}$ and $\mathrm{E}$. coli. The mean contamination by at $35^{\circ} \mathrm{C}$ and coliforms at $45^{\circ} \mathrm{C}$ were $3,1 \times 10^{2} \mathrm{MPN} / \mathrm{g}$ and $7.7 \mathrm{MPN} / \mathrm{g}$ respectively. The presence of E. coli was verified in five samples, representing an occurrence of $8.3 \%(5 / 60)$, and Salmonella spp. in 5\% (03/60) of the analyzed samples. The MPN (Most Probable Number) average of coliforms at $35^{\circ} \mathrm{C}$ and $45^{\circ} \mathrm{C}$ are in accordance to national and international legislation; however, the presence of Samonella spp., E. coli in some sample indicates a low risk of occurrence of salmonellosis and colibacillosis transmitted by the evaluated beef. However, transmission risk of these diseases cannot be ruled out, since the presence of E. coli does not depend on the amount of coliforms and national legal standards established for the group of thermotolerant coliforms.
\end{abstract}

Key words: coliforms, Escherichia coli, Salmonella spp., meat.

Condições higiênico sanitárias de carne embalada a vácuo produzida por abatedouros frigoríficos habilitados a exportação no estado de Mato Grosso, Brasil

RESUMO: O Brasil é o maior exportador de carne bovina do mundo e Mato Grosso é o maior produtor de carne bovina do país. Para manter a competitividade do produto e a expansão do mercado, o controle higiênico sanitário de todo o processo é indispensável para garantir a obtenção de carne inócua e de qualidade. O objetivo desse estudo foi avaliar as condições higiênico sanitárias da carne bovina resfriada embalada a vácuo, não maturada produzida por estabelecimentos detentores de Serviço de Inspeção Federal (SIF) no estado de Mato Grosso. Um total de 60 amostras foram submetidas a contagem de coliformes à $35^{\circ} \mathrm{C}$, coliformes à $45^{\circ} \mathrm{C}$, pesquisa de E. coli e Salmonella spp. A contaminação média por coliformes à $35^{\circ} \mathrm{C}$ e coliformes à $45^{\circ} \mathrm{C}$ da carne bovina mato-grossense inspecionada pelo SIF foi 3,1 x $10^{2} \mathrm{NMP} / \mathrm{g}$ e 7,7NMP/g, respectivamente. A presença de E. coli foi verificada em cinco amostras o que representou uma ocorrência de $8,3 \%$ (5/60) $e$ Salmonella spp. em 5\% (3/60). Foi avaliado que a média NMP de coliformes à $35^{\circ} \mathrm{C}$ è $45^{\circ} \mathrm{C}$ atende a legislação nacional e internacional, no entanto, a verificação da presença de Salmonella spp., E. coli em algumas amostras, evidenciou um baixo risco de ocorrência de salmonelose ou colibacilose transmitidas pela carne. Ainda assim, não se pode descartar o risco de veiculação dessas doenças, uma vez que a presença de E. coli independe da quantidade de coliformes e dos padrões legais nacionais estabelecidos para o grupo dos coliformes termotolerantes. Palavras-chave: coliformes, Escherichia coli, Salmonella spp., carne bovina.

Brazil is the second largest producer of beef in the world, being surpassed only by the USA. Meanwhile, Brazil is the largest exporter of this product, with supply to more than 100 countries, the Mato Grosso State is the highest meat producer in Brazil (ABIEC, 2016; BRASIL, 2016). To maintain product competitiveness and market expansion, sanitary hygienic control of the entire process is indispensable to ensure the attainment of harmless beef and adequate quality. This is currently especially true because of the recent events of the so-called "weak meat operation" that raised doubts about Brazilian meat safety. Thus, studies are being conducted to characterize and evaluate the contamination of this type of product in Brazil (SANTOS, et al. 2017). 
Brazil's Resolution RDC No 12 (BRASIL, 2001) establishes microbiological standards for food; however, it does not establish references for coliforms at $35^{\circ} \mathrm{C}$ and $E$. coli in vacuum-packed, fresh-frozen beef. Conversely, Brazilian beef importers demand the evaluation of these quality indicators.

Currently, some Brazilian slaughterhouses were authorized to sell fresh chilled and frozen beef to the USA. Therefore, it is extremely important to evaluate these products, as these buyers, as well as Brazil, demand the total safety of beef, since these foods are related to the presence of pathogenic microorganisms, such as Salmonella spp. and Escherichia coli, originated from fecal contamination. In this regard, there is need for further studies devoted to the study of the microbiological profile of packaged vacuum beef, since the detection of these microorganisms in indispensable product safety. Thus, in this study, the hygienic sanitary conditions of vacuum-packed cooled fresh beef, produced by slaughterhouses in the state of Mato Grosso qualified for export to different countries of the world were evaluated.

A convenience sample was established according to the number of bovine abattoirs under permanent supervision by the Brazilian Federal Inspection Service (SIF) in the state of Mato Grosso. Thus, a total of 60 samples of fresh beef packaged under vacuum, cooled and not mature, were obtained from nine cattle slaughtering establishments, all authorized for export. The samples were cooled to between $1^{\circ} \mathrm{C}$ and $7^{\circ} \mathrm{C}$, had average weight of $1.5 \mathrm{~kg}$, and were composed of individual bovine meat cuts such as shoulder clod (triceps brachii), brisket (pectoralis superficialis), roast beef (longissimus dorsi), eye cap (trapezius thoracis), rump cap (Biceps femoris), rump (gluteus medius), eye of round (semitendinosus) and tenderloin (psoas major).

Samples were submitted to microbiological analyzes, in triplicate, for quantification of coliforms at $35^{\circ} \mathrm{C}$, coliforms at $45^{\circ} \mathrm{C}$, E. coli and Salmonella spp., based on the APHA method (KORNACKI \& JOHNSON, 2001). Suspected Salmonella spp. colonies were also subjected to Polymerase Chain Reaction (PCR) to amplify the hilA gene, that is genusspecific and one of the main transcriptional regulators of other invasion genes (GUO et al., 2000; BAJAJ, et al., 1995). Results were interpreted according to the indication of each method and compared with the microbiological references and standards established by Resolution RDC N .12 (BRASIL, 2001).

The average beef coliform contamination at $35^{\circ} \mathrm{C}$ and $45^{\circ} \mathrm{C}$ were $3.1 \times 10^{2} \mathrm{MPN} / \mathrm{g}$ and $7.7 \mathrm{MPN} / \mathrm{g}$, respectively. The presence of $E$. coli was observed in five samples, representing an occurrence of $8.3 \%$ $(5 / 60)$ and Salmonella spp. in 5\% (03/60) of the analyzed samples. The mean coliforms at $35^{\circ} \mathrm{C}$ and coliforms at $45^{\circ} \mathrm{C}$ were calculated according to the 60 analyzed samples, and only samples with coliforms counts in the MPN table or showing the presence of $E$. coli and Salmonella spp. are listed in table 1.

Considering these results, a low average count of coliforms at $45^{\circ} \mathrm{C}$ was observed, according to ANVISA's sub item h of RDC $\mathrm{N}^{\circ}$. 12. Low occurrence of $E$. coli was also detected; although, some samples $(5875,7627$ and 7649$)$ exceeded the maximum limit for coliforms at $45^{\circ} \mathrm{C}$ (BRASIL, 2001).

The average coliforms counts at $35^{\circ} \mathrm{C}$ and $45^{\circ} \mathrm{C}$ were lower than other studies that evaluated the microbiological quality of beef produced and marketed in different Brazilian states (OLIVEIRA et al., 2002; OLIVEIRA et al., 2008; ROSINA et al., 2013). This contamination is directly related to GMP, Standard Operating Procedures (SOP), and Hazard Analysis and Critical Control Points (HACCP), considering that coliform samples with MPN above $10^{3}$ were from different slaughtering establishments, many of them were not eligible for export (Table 1). Thus, it is possible to verify the natural variation betweenapplication of existing quality program tools between the different slaughtering establishments.

$E$. coli was detected in some analyzed samples (3413, y011, 7627, 7649, 2569). E. coli beef research is required by several meat importing countries as a quality and food safety indicator. The occurrence of $E$. coli in vacuum-packed beef is independent of $\mathrm{MPN} / \mathrm{g}$ of coliforms at $45^{\circ} \mathrm{C}$, but its presence indicates fecal contamination, possible existence of other pathogens and the risk of colibacillosis transmission by pathogenic E. coli (GILL, 1998). This was also observed in slaughtering establishments with federal and provincial registration in Canada, where a significant statistical correlation between coliform counts and the presence of $E$. coli was not verified (JONES et al., 2014).

The presence of Salmonella spp. was verified in the samples 2573, 3587 and 2547 representing an occurrence of $5 \%$, in disagreement with the Brazilian legislation (BRASIL, 2001) making those samples unfit for human consumption. Other studies carried in the state Mato Grosso on both meat from butchers and vacuum packed beef, detected a Salmonella spp. occurrence of $17 \%$ and $5.6 \%$ of respectively (SOUZA et al., 2012).

The presence of E. coli and Salmonella spp. identified in the samples of the present study came from four and two different slaughtering 
Table 1 - Coliform counts, E. coli and Salmonella spp. research on cooled fresh beef, produced by slaughterhouses qualified for export in the Mato Grosso State, Brazil.

\begin{tabular}{|c|c|c|c|c|c|}
\hline Sample ${ }^{* *}$ & Total Coliforms (MPN/g) & Coliforms $45^{\circ} \mathrm{C}(\mathrm{MPN} / \mathrm{g})$ & E. coli & Salmonella spp. & Slaughterhouses \\
\hline 3586 & $<3.0$ & 9,2 & A & A & I \\
\hline 3412 & 3,6 & $<3,0$ & A & A & I \\
\hline 3587 & 3,6 & $<3,0$ & A & $\mathrm{P}^{*}$ & I \\
\hline 3407 & 3,6 & 3,6 & A & A & I \\
\hline 3585 & 3,6 & 3,6 & A & A & I \\
\hline 2573 & 3,6 & 3,6 & A & $\mathrm{P}^{*}$ & I \\
\hline 3408 & 7,4 & 3,6 & A & A & I \\
\hline 1343 & 15 & 3,6 & A & A & I \\
\hline 2566 & 23 & $<3,0$ & A & A & I \\
\hline 3583 & 23 & 23 & A & A & I \\
\hline 2571 & 43 & 43 & A & A & I \\
\hline 2568 & 43 & $<3,0$ & A & A & I \\
\hline 7443 & $>1,1 \times 10^{3}$ & $<3,0$ & A & A & I \\
\hline 2572 & $4,6 \times 10^{2}$ & 9,2 & A & A & I \\
\hline 3413 & 15 & 1,5 & $\mathrm{P}$ & A & I \\
\hline 2569 & 93 & 23 & $\mathrm{P}$ & A & I \\
\hline 2907 & 3,6 & 3,6 & A & A & II \\
\hline 7649 & $>1,1 \times 10^{3}$ & $>1,1 \times 10^{3^{*}}$ & $\mathrm{P}$ & A & II \\
\hline 2902 & 3,6 & $<3,0$ & A & A & III \\
\hline X002 & 3,6 & $<3,0$ & A & A & IV \\
\hline y009 & 9,2 & 3,6 & A & A & IV \\
\hline y012 & 9,2 & $<3,0$ & A & A & IV \\
\hline y010 & 23 & 23 & A & A & IV \\
\hline y013 & 23 & 3,6 & A & A & IV \\
\hline X004 & 44 & $<3,0$ & A & A & IV \\
\hline X001 & 93 & $<3,0$ & A & A & IV \\
\hline X003 & $1,1 \times 10^{3}$ & 3,6 & A & A & IV \\
\hline X006 & $1,1 \times 10^{3}$ & $<3,0$ & A & A & IV \\
\hline y014 & $1,1 \times 10^{3}$ & $1,1 \times 10^{3^{*}}$ & A & A & IV \\
\hline X005 & $>1,1 \times 10^{3}$ & 3,6 & A & A & IV \\
\hline y011 & 9,2 & 9,2 & $\mathrm{P}$ & A & IV \\
\hline 5875 & $>1,1 \times 10^{3}$ & $>1,1 \times 10^{3^{*}}$ & A & A & $\mathrm{V}$ \\
\hline 7627 & $>1,1 \times 10^{3}$ & $>1,1 \times 10^{3^{*}}$ & $\mathrm{P}$ & A & VI \\
\hline 2547 & $<3,0$ & $<3,0$ & A & $\mathrm{P}^{*}$ & VII \\
\hline $\mathrm{X}^{* * *}$ & $3,1 \times 10^{2}$ & 7,7 & & & \\
\hline S & $4,7 \times 10^{2}$ & 9,3 & & & \\
\hline
\end{tabular}

$\mathrm{X}=$ Average; $\mathrm{S}=$ standard deviation; $\mathrm{A}=$ absence; $\mathrm{P}=$ presence MPN $=$ Most probable number per gram; ${ }^{*}$ Exceeded limit in accordance to subitem h of RDC No. 12 (BRASIL, 2001); ${ }^{* *}$ Only samples with counts above 3.0 MPN for coliforms, presence of E. coli or Salmonella spp.; ${ }^{* * *}$ Average calculated according to 60 samples.

establishments respectively (Table 1), and, especially regarding Salmonella spp., most underwent SIF inspection. In this regard, studies that identify and report these results are extremely necessary, since the presence of these pathogens makes products unacceptable and interferes with the purchase of these foods by other countries.

Thus, it was evaluated that MPN average of coliforms at $35^{\circ} \mathrm{C}$ and coliforms at $45^{\circ} \mathrm{C}$ are in attendance to national and international legislations; although, the presence of $E$. coli in the groups of coliforms at $45^{\circ} \mathrm{C}$ is not related to the amount of coliforms or legal standards, which does not rule out the risk of transmission of this pathogen and its sorogroups. Likewise, the presence of Salmonella spp. in some samples indicated that; although low, the risk for dissemination of diseases such as salmonellosis exists.

Ciência Rural, v.48, n.4, 2018. 


\section{ACKNOWLEDGEMENTS}

The authors would like to thank funding agency Fundação de Amparo à Pesquisa do Estado de Mato Grosso (FAPEMAT) that enabled the development and implementation of this research.

\section{DECLARATION OF CONFLICTING INTERESTS}

None of the authors of this paper has a financial or personal relationship with other people or organizations that could inappropriately influence or bias the content of the paper.

\section{REFERENCES}

ABIEC. Brazilian Association of Meat Exporting Industries. Brazilian Beef Exports. 2016 Available from: <http://www. abiec.com.br/download/exportacoes-jan-dez-2016.pdf $>$. Accessed: May 19, 2017

BAJAJ, V.; HWANG; LEE, C. A. hil A is a novel ompRtoxR family member that activates the expression of Salmonella typhimurium inavasion genes. Blackwell Science Ltd. Molecular microbiology, Boston. 1995, p. 715-727. Available from: <https://www.ncbi.nlm. nih.gov/pubmed/8817493>. Accessed: Jul. 29, 2017. doi: 10.1111/ j.1365-2958.1995.mmi_18040715.x.

BRASIL. ANVISA (NATIONAL SANITARY SURVEILLANCE AGENCY). Technical regulation on microbiological standards for food. Resolution RDC no. 12, of January 2, 2001. Official Journal of the Union, Brasília-DF, $\mathrm{n}^{\circ}$ 7, jan. 2001. Available from: <http://portal.anvisa.gov.br/documents/33880/2568070/ RDC_12_2001.pdf/15 ffddf6-3767-4527-bfac740a0400829b>. Accessed: Jul. 29, 2017.

BRASIL. Ministry of Agriculture, Livestock and Supply. Cattle and buffaloes. Feb. 2016. Available from: <http:// www.agricultura.gov.br/animal/especies/bovinos-e-bubalinos $>$. Accessed: Sept. 17, 2016.

GILL, C.O. Microbiological contamination of meat during slaughter and butchering of cattle, sheep and pigs,. In: Davies, A. \& Board, R. (Eds.), The Microbiology of Meat and Poultry. Blackie Academic and Professional, London. 1998, p. 118-157.
GUO, X. et al. PCR detection of Salmonella enterica serotype Montevideo in and on raw tomatoes using primers derived from hila. Applied and Environmental Microbiology, 2000, p. 5248-5252. Available from: <https://www.ncbi.nlm.nih.gov/pmc/ articles/PMC92452/>. Accessed: Sept. 17, 2016.

JONES, T. H. et al. Numbers of coliforms, Escherichia coli, F-RNA phage, rotavirus, bovine enteric calicivirus and presence of non-O157 STEC on commercial vacuum packaged beef. Food Microbiology, v. 42, p. 225-231, 2014. Available from: <http://www.sciencedirect. com/science/article/pii/S0740002014000768?via\%3Dihub>. Accessed: Jul. 09, 2017. doi: 10.1016/j.fm.2014.04.001.

KORNACKI, J. L. \& JOHNSON, J. L. Enterobacteriaceae, coliforms and Escherichia coli as quality and safety indicators. In: DOWNES, F.P. and K.ITO (ed). Compendium of Methods for the Microbiological Examination of Foods, 4 ed. American Public Health Association (APHA), Washington, D.C., 2001. Chapter 8, p.69-82.

OLIVEIRA, N. M. S.; et al. E. Isolation and identification of mesophilic facultative bacteria in fresh bovine and porcine meat. Food Hygiene, São Paulo, v. 16, n. 94, p.68-74, 2002. Available from: <http://pesquisa. bvsalud.org/sms/resource/pt/lil-307841>. Accessed: Jul. 29, 2017.

OLIVEIRA, S. et al. Evaluation of hygienic sanitary conditions of beef sold in supermarkets in João Pessoa. João Pessoa: Food and nutrition, 2008. Available from: <http://seer.fcfar.unesp.br/aen/ index.php/aen/search/search>. Accessed: Jul. 29, 2017.

ROSINA, A.; MONEGO, F. Microbiological evaluation of ground beef in the supermarket chains of Canoinha/SC. Santa Catarina: Health and Environment. V. 2, n. 2, 2013, p. 55-64. Available from: $<$ http://www.periodicos.unc.br/index.php/sma/article/view/468>. Accessed: Jul. 29, 2017. doi: 10.24302/sma.v2i2.468.

SANTOS, E. C. C. et al. Evaluation of the Sanitary Conditions of Head Meat, Esophagus, Diaphragm Meat, and Boning Scrap Processing. Journal of Food Quality, v.2017, p. 1-4, 2017. Available from: $<$ https://www.hindawi.com/journals/jfq/2017/3230596/>. Accessed: Jul. 29, 2017. doi: 10.1155/2017/3230596.

SOUSA, T. M. et al. Pathogenic microorganisms and indicators of hygienic-sanitary conditions in ground beef marketed in the city of Barra do Garças, MT, Acta Vet. Bras., vol. 6, no. 2, pp. 124-130, Nov. 2012. Available: <https://periodicos.ufersa.edu.br/revistas/ index.php/acta/article/view/2646>. Accessed: Jul. 29, 2017. doi: 10.21708/avb.2012.6.2.2646. 